\title{
Dendritic cell vaccination and immune monitoring
}

\author{
E. H. J. G. Aarntzen · C. G. Figdor · G. J. Adema • \\ C. J. A. Punt · I. J. M. de Vries
}

Received: 4 February 2008 / Accepted: 18 June 2008 / Published online: 10 July 2008

(C) The Author(s) 2008

\begin{abstract}
We exploited dendritic cells (DC) to vaccinate melanoma patients. We recently demonstrated a statistical significant correlation between favorable clinical outcome and the presence of vaccine-related tumor antigen-specific $\mathrm{T}$ cells in delayed type hypersensitivity (DTH) skin biopsies. However, favorable clinical outcome is only observed in a minority of the treated patients. Therefore, it is obvious that current DC-based protocols need to be improved. For this reason, we study in small proof of principle trials the fate, interactions and effectiveness of the injected DC.
\end{abstract}

This article is a symposium paper from the conference "The European Society for Medical Oncology (ESMO) and the European Society for Cancer Immunology and Immunotherapy (ESCII) International Symposium on Immunology", held in Athens, Greece, on 15-17 November 2007.

E. H. J. G. Aarntzen · C. J. A. Punt · I. J. M. de Vries Department of Medical Oncology,

Nijmegen Centre for Molecular Life Sciences, Radboud University Nijmegen Medical Centre,

Nijmegen, The Netherlands

E. H. J. G. Aarntzen · C. G. Figdor · G. J. Adema - I. J. M. de Vries Department of Tumor Immunology,

Nijmegen Centre for Molecular Life Sciences, Radboud University Nijmegen Medical Centre, Nijmegen, The Netherlands

I. J. M. de Vries

Department of Pediatric Hemato-Oncology, Nijmegen Centre for Molecular Life Sciences, Radboud University Nijmegen Medical Centre, Nijmegen, The Netherlands

I. J. M. de Vries $(\square)$

Geert Grooteplein 26, 6525 GA Nijmegen, The Netherlands

e-mail: j.devries@ncmls.ru.nl
Keywords Dendritic cells · Specific immune responses · Migration $\cdot$ mRNA transfection $\cdot$ In vivo targeting

\section{Antigen-presenting dendritic cells}

DC are the professional antigen-presenting cells (APC) of the immune system that instruct and control the activation of $\mathrm{B}$ and $\mathrm{T}$ lymphocytes, the mediators of specific immunity [5]. DC are highly mobile cells and by their sequential migration from peripheral tissues to lymphoid organs they serve as sentinels of the immune system. Immature DC are very efficient in antigen uptake, mediated by high endocytotic activity and expression of an array of cell surface receptors capable of capturing antigens [34, 53]. Inflammatory mediators and 'danger signals' promote maturation and re-routing of DC to the secondary lymphoid organs [5, 43]. In the secondary lymphoid tissues, DC are mature and well equipped to attract, interact and activate naive $\mathrm{T}$ cells to initiate a primary immune response $[1,5]$. DC are also able to directly activate NK cells [26] and can produce large amounts of interferon upon encounter with viral pathogens [36], thus, providing a link between the adaptive and innate immune system. In murine tumor models, protective immunity as well as regression of established tumors have been observed after vaccination with DC loaded with tumor antigens [13, 44, 66]. Their unique capacity to initiate and modulate immune responses is currently exploited by many groups, including ours, to fight infectious diseases and cancer.

One aspect of DC biology that is rapidly evolving is the apparent diversity of DC-subsets [59]. At least two distinct ontogenic pathways for DC development have been reported, the myeloid progenitor- and the lymphoid progenitor-derived DC [40]. Part of these different DC-subsets 
may also be explained by differences in the maturation stage of DC and the local cytokine environment. The geographical localization of the DC-subsets in secondary lymphoid tissues is distinct, myeloid derived DC mainly migrate to or reside in the marginal zone (a primary entry point for blood-born antigens), whereas the lymphoid DC mainly reside in the T-cell areas. This supports distinct functions for the DC-subsets, as shown in murine studies $[5,40]$. It is now well appreciated that the DC subset, its maturation state and the microenvironment or type of pathogen a DC encounters in the periphery, determine the type of immune response that is induced, ranging from a TH1 or $\mathrm{TH} 2$ response to immune tolerance $[38,40,51]$.

Data are now accumulating that immature DC can induce tolerance and are able to induce regulatory $\mathrm{T}$ cells in vitro [35, 54] and in vivo [20]. Regulatory $\mathrm{T}$ cells are involved in the control of peripheral tolerance [57] and the prevention of vigorous inflammatory reactions. These regulatory $\mathrm{T}$ cells affect immune responses at the level of antigen-presentation and during the effector phase of $\mathrm{T}$ cells at the site of the tumor. Although the exact mechanisms by which regulatory $\mathrm{T}$ cells exert their suppressive functions are not yet elucidated, direct cell-cell contact and cytokines like IL-10 and TGF $\beta$ have demonstrated to play a role. Our data on vaccination of melanoma patients also demonstrate that mature DC, but not immature DC, induce strong immune responses in vivo [19].

Another aspect in the evolving field of immunotherapy is the re-acknowledgement of the role of the innate immune system. The eradication of a malignancy is the result of a concerted action of adaptive and innate immunity, in which natural killer (NK) cells and natural killer T (NKT) cells are important effector cells [37]. Next to the direct cytotoxic effect on tumor cells, NK cells produce type I interferons that contribute to a great extent to a proinflammatory microenvironment. Clinical studies on adoptive NK-cell immunotherapy have shown that NK cells can target human tumors [45, 52].

\section{DC-based cancer vaccines: current status}

Over 60 different clinical studies have been carried out between 1996 and 2004, applying tumor antigen-loaded DC-based vaccines [60]. The vast majority of these studies have been performed in melanoma patients [27, 49]. In our studies, as well as in other groups, immunological and, notably long-lasting, clinical responses have consistently been observed following cellular therapy $[6,27,46]$. In several patients these clinical responses coincide with the induction of specific cytotoxic T-cell responses.

We have explored vaccination of cancer patients with monocyte-derived DC loaded with peptides derived from tumor-associated antigens. In our current culture protocol
[17], we routinely generate large amounts of clinical grade mature and immature DC. DC maturation is induced using MCM, TNF $\alpha$ and $\mathrm{PGE}_{2}$. The first DC trial at our institution has been initiated in 1998. Herein, the safety of DC-based vaccines and the efficacy of immature DC versus mature DC was studied. HLA-A2.1+, gp100+, tyrosinase+ metastatic melanoma patients were treated with peptide-pulsed immature or mature DC. As peptides we used two HLAA2.1 restricted gp100 peptides (either native or modified peptides to improve their HLA-A2.1 binding affinity) [3, 4] and a tyrosinase peptide [10]. All DC vaccines were co-loaded with the foreign protein KLH (Calbiochem, Darmstadt, Germany) that serves as a control for immune competence and stimulation of a T-helper response. Vaccinations were given 3 times with 2-week intervals, followed by injections with the peptides alone. Immune monitoring consisted of (1) DTH responses with pulsed DC and unpulsed DC, (2) ELIspot-assays [31, 55] and (3) tetramer assays $[2,22,30]$. In addition to peripheral blood, immune monitoring was also performed using biopsies taken from DTH sites (see later).

The results of the first clinical trial have been published [19], and unequivocally demonstrated that mature but not immature DC are capable of inducing potent anti-KLH-specific T-cell, and B-cell responses [19]. Clinical results demonstrated that $3 / 20$ objective remissions were observed in stage IV melanoma patients vaccinated with mature DC. In this group 10 patients were vaccinated with mature DC, of these patients 1 was not evaluable because of detoriating condition and of the remaining 9 patients, 3 showed stable disease $>4$ months (respectively, 4.5, 7.5 and 22) 1 patient showed a mixed response and 1 patient achieved a partial response with complete remission after surgical intervention, that now lasts $>7$ years. All patients in this study were melanoma patients with metastatic disease (M1c, 1 patient M1a) in WHO performance status 0 . Moreover, clinical results correlated with the presence of vaccine-induced immune responses against the tumor peptides (see later) [15].

To date, $>200$ melanoma patients have been vaccinated in our ongoing DC-trials, we observed no clinical benefit from vaccinations in patients with high-tumor load (as judged by the clinician), elevated serum LDH, brain metastases or rapid progressive disease. Therefore, we excluded these patients, with a life expectancy less than 3 months, in ongoing studies. While on the down side the vaccine is not yet very effective, with an objective clinical response rate (i.e. $>1$ year SD or better, stage IV melanoma patients) of approximately $10-15 \%$, the positive message is that we clearly find T cell-mediated immunological responses: $60 \%$ in patients with regional lymph node metastasis and 30\% in patients with metastatic disease. Patients exhibiting these responses show an significantly improved progression free survival. 
Nevertheless, a number of variables need to be evaluated and controlled to further improve clinical outcome in cellular therapies, among these are generation of DC, use of different DC-subsets, route of administration, optimal activation stimuli for DC [8], antigen loading of dendritic cells, selection of tumor-derived antigens and so on [27]. These variables are in ongoing debate, but one can conclude that the full potential of DC-based cellular therapy has not yet fully been exploited. However, the current consensus is to continue cellular therapy in well-designed small trials that meet a standardized list of quality criteria. This consensus list should at least describe quality-control criteria for ex vivo generated DC, patient characteristics, trial design including the different variables that are investigated, and tests for clinical and immunological responses [27, 33].

Significant progress in cellular therapy against cancer, including DC vaccination, is only to be expected by careful immune monitoring studies in order to obtain detailed insight of the underlying (pathological) physiological processes that determine the success or failure of treatment. Different compartments and modalities are considered to monitor induced immune responses; e.g. accuracy of delivery, immune responses in peripheral blood, tumor and delayed type hypersensitivity (DTH) test biopsies, and clinical evaluation. Recently, it was shown that the modality of vaccination with a tumor-specific antigen influences the differentiation pathway of the anti-vaccine CD8 T cells, which may have an effect on their capacity to trigger a tumor rejection response [14]. Palucka et al. [48] observed that patients with a high-baseline level of melanoma antigen-specific immunity more often show an immune response to the vaccine. Furthermore, they show that patients who survived longer are those who showed immune response against two melanoma antigens presented on the DC vaccine [25]. Although sometimes correlations between tumor regression and $\mathrm{T}$-cell responses are observed [25, 41], the immunological studies performed so far are too diverse in their setup to pool them in a metaanalysis [11]. However, some lessons can be drawn from these studies. For example, an intact and proper functioning immune system seems to have a higher potential to react on immune therapy. From our immune monitoring data, mentioned below, we might not only conclude that the presence of tetramer-specific T cells is correlated with an improved progression free survival. Another conclusion should be that in the end-stage melanoma patients these tetramer-specific $\mathrm{T}$ cells are less frequently induced ( 8 of 26 patients) than in melanoma patients with regional lymph node metastasis (24 of 31 patients).

Secondly, upon induction of tumor antigen-specific $\mathrm{T}$ cells, the next hurdle to take is the local immune suppressive environment created by the tumor. In the end-stage melanoma patients, the misbalance is already in favor of the metastasizing tumor. In our ongoing studies we have seen that in some patients tetramer-specific $\mathrm{T}$ cells are present after DC vaccination, but still experience progression. It became clear that these tetramer-specific $\mathrm{T}$ cells did not produce interferon- $\gamma$ nor showed cytotoxic activity upon tumor challenge. Apparently, these effector cells were not capable of breaking the local suppressive tumor-environment.

We might take better advantage of the unique capacity of DC to direct the immune response by exploiting DC-based cellular therapy earlier in the disease course. It has been demonstrated that already in sentinel nodes melanoma-specific $T$ cells are present, together with antigen-presenting cells. In this window between primary tumor and metastasis, immunological processes can be crucial. It might be at this turning point in the development of melanoma, that ex vivo generated DC can assist the immune system.

\section{DC migration in vivo}

For DC to induce potent immune responses their migration towards lymph nodes is essential. In mice, we have demonstrated that major differences can be found in numbers of migrating DC depending on the route of administration (subcutaneous gave the best results) and the maturation state (mature gave the best results) [23]. With respect to the latter we were able to confirm these data in stage III melanoma patients with lymph node metastases who were scheduled for radical lymph node resection [18]. During the first vaccination these patients received an injection of ${ }^{111}$ Indium-labeled mature or immature DC to allow scintigraphic imaging to study in vivo migration [18]. Regardless of the route of administration (intradermal or intranodal) mature DC were more efficient than immature DC in reaching the draining lymph node in vivo [18].

The results described earlier were obtained by our developed method of radioactive labeling of DC (Fig. 1) [18, 23]. DC have therefore been labeled with radionuclides for scintigraphic imaging of cell trafficking, which is until to date the only FDA-approved clinical cellular imaging modality [18, 42]. A major drawback of scintigraphy, however, is the lack of anatomical detail allowing only gross anatomical determination of migration between LNs without the ability to assess the intranodal distribution pattern of DC within each LN. Furthermore, due to its low spatial distribution, accurate delivery of cells which may be essential for subsequent migration into nearby lymph nodes cannot be properly evaluated using scintigrapy. In contrast, MR imaging is well suited to obtain 3D whole body high-resolution images and is widely used in clinical practice. The currently most sensitive markers to label cells for MR detection are (ultrasmall) superparamagnetic iron oxide 
Fig. 1 Monitoring the accuracy of delivery of SPIO-labeled cells using MR imaging and scintigraphy. Monocytes are obtained by cytopheresis from stage III melanoma patients (a), they are cultured and labeled with SPIO particles and ${ }^{111}$ Indium (b). The cells are then injected intranodally into the lymph node basin that is to be resected and their biodistribution is monitored in vivo by scintigraphy (c) and MRI (d). The lymph node basin is resected (e) and separate lymph nodes are visualized with high-resolution MRI at 7 Tesla (f) and histology (g)
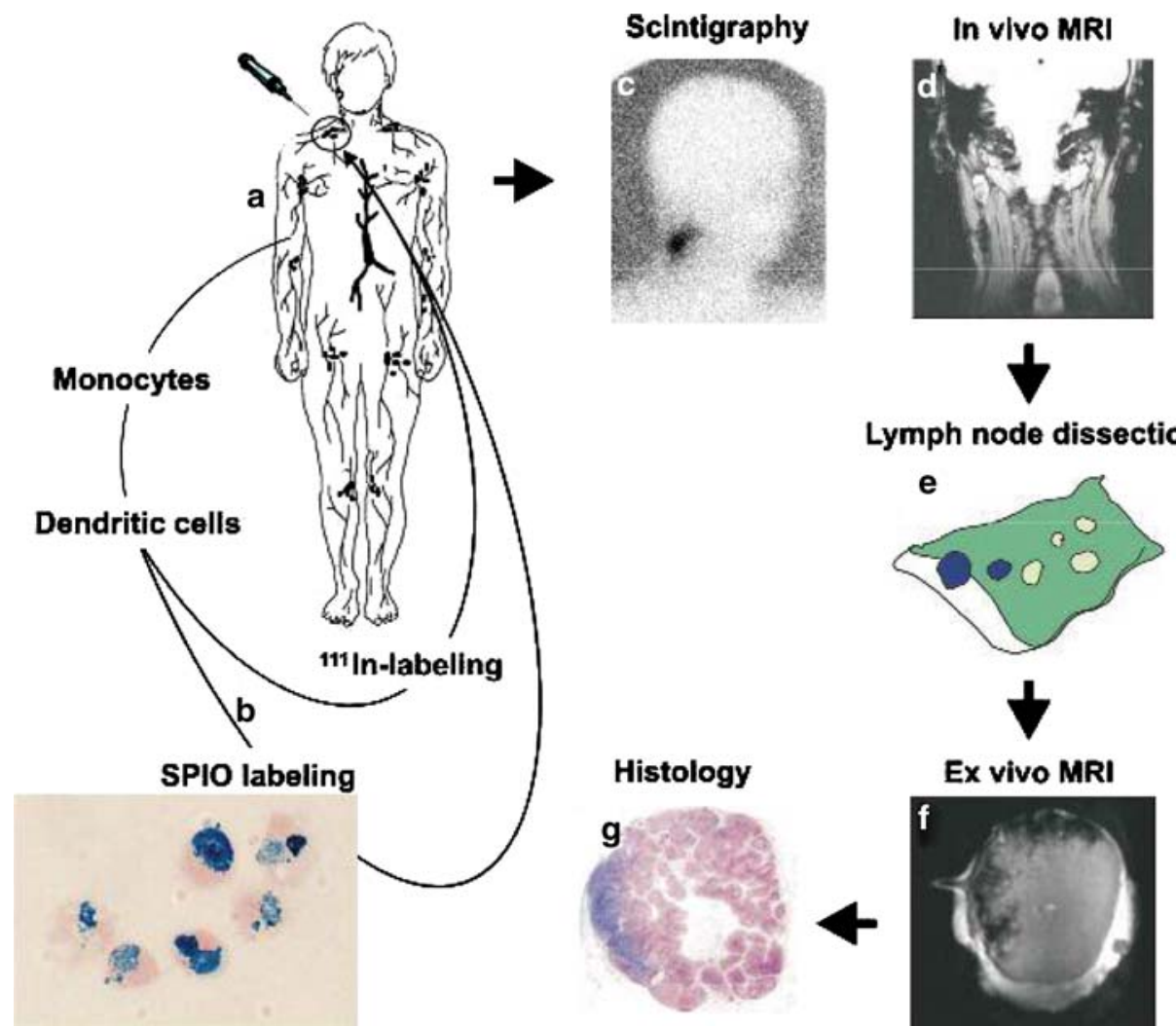

Lymph node dissection
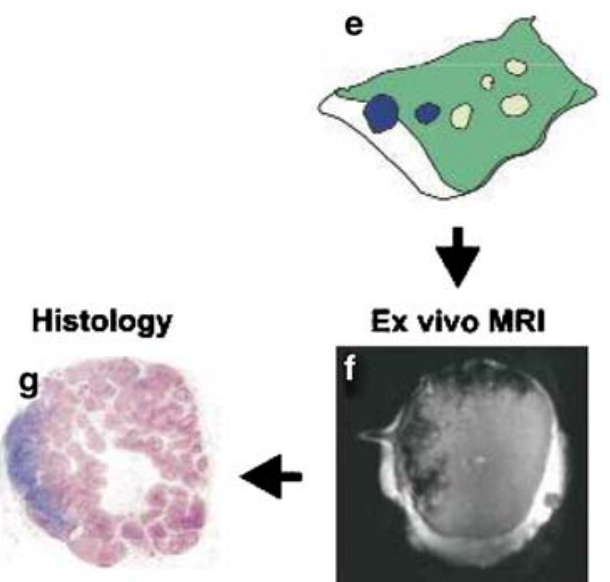

[(U)SPIO] particles [12]. We took advantage of the fact that DC naturally endocytose clinically applied, FDA-approved SPIO-labels in significant amounts, obviating these concerns. This provided us with the opportunity to label cells with high efficiency without affecting their function and use these cells in humans [63].

We investigated the biodistribution of these SPIO-prelabeled DC applied as cancer vaccines in melanoma patients using MR imaging. In our DC vaccination protocols, in vitro generated DC loaded with tumor-derived antigenic peptides were administered to stage III melanoma patients as outlined in Fig. 1 [18, 19]. DC were labeled with ${ }^{111}$ In-oxine and SPIO (Endorem ${ }^{\circledR}$ ) separately and co-injected in $\mathrm{LN}$ in the lymph node basin to be resected. This provided the unique opportunity to not only obtain MR scans at 3 Tesla ( $\mathrm{T}$ ) before surgery but also to generate high-resolution MR images at $7 \mathrm{~T}$ of individual resected LNs, and to correlate the results with scintigraphy and (immunology) histopathology. Interestingly, we found that in only approximately $50 \%$ of the cases DC were correctly injected into the LN, despite ultrasound guidance of the injection needle by a highly experienced radiologist. Subsequent migration could be observed only when DC were correctly injected into the lymph node, demonstrating not only the importance of accurate delivery but also of careful monitoring of cell tracking in cellular therapy. Inadequate delivery may be an important reason why only a limited proportion of patients respond in ongoing clinical trials using DC vaccines. We found that the accuracy of MR imaging to visualize truly DC-positive LNs was significantly better than scintigraphy. These findings illustrate the power of additional anatomical information, which can also be of value for other fields of biomedical research.

With Prussian blue staining we can visualize SPIOlabeled cells. We observed immunohistologically that the SPIO-labeled DC that do migrate enter the lymph nodes via the sinuses and reach the T-cell areas where the actual DC$\mathrm{T}$ cell interaction takes place. At this stage we were able to demonstrate that intranodally injected SPIO-labeled DC, electroporated with RNA encoding the tumor antigen gp100, express the gp100 protein. From resected lymph nodes rosettes, containing SPIO-labeled DC surrounded by enlarged and activated T cells, were isolated. So we disclosed the desired "functional unit" within a lymph node.

\section{Immune monitoring in tissues}

Another aspect is monitoring the immune response that is thought to induce tumor regression. Immune monitoring is most straightforward after vaccination with defined antigens, however, responses have also been detected after lysate or total RNA-loaded DC vaccines. Fortunately, many novel tools are now available to detect immune responses against known and unknown tumor antigens, including MHC-tetramers, Eli-spot assays and cytokine release/catch 
assays [2, 22, 31, 55]. No correlation was observed between the reactivity against KLH and the clinical outcome. We developed a novel approach to efficiently monitor DC vaccine related T-cell responses in vaccinated patients using biopsies derived from DTH sites [15]. The results of this monitoring method correlated with the clinical outcome in stage III and IV melanoma patients.

DTH challenges consisting of peptide-loaded DC plus or minus KLH, DC loaded with KLH, and unloaded DC revealed that essentially all patients mounted a positive DTH response with indurations up to $33 \mathrm{~mm}$. As both unloaded DC and DC loaded with KLH and/or peptides were positive, indurations at the DTH site were not predictive of vaccine-related T-cell responses in our setting. However, as no DTH was detected after the first intradermal injection of the vaccine, the occurrence of a positive DTH reaction should be directly related to the vaccination. The reason for the DTH response to unloaded DC is not clear but could be explained by the vast amount of chemokines produced by mature DC [17].

Punch biopsies $(6 \mathrm{~mm})$ were taken from positive DTH sites and divided in half. One part was used for histochemistry and the other part was used to isolate DTH-infiltrating leukocytes (DIL). Immune staining showed clusters of $\mathrm{CD} 2+$ and $\mathrm{CD} 3+$ infiltrating cells of which $50-70 \%$ were CD4+ and 50-30\% were CD8+ T cells. No clusters of infiltrating cells were observed in unchallenged control skin biopsies. DIL were generated by cutting the biopsies in pieces and culturing of the outgrowing cells for 2-3 weeks in the presence of low dose IL-2 $(100 \mathrm{U} / \mathrm{ml})$ without restimulation. Interestingly, DIL specific for KLH could easily be found in biopsies from KLH-pulsed DC, not in DIL from peptide or unpulsed DTH biopsies. Moreover, in 11 (6 stage III, 5 stage IV) of 22 patients tested, gp100/tyr tetramer-positive T-cell populations were readily detected. In 5 additional patients, antigen-specific cytotoxic $\mathrm{T}$ cells in DIL cultures were detected after additional vaccination cycles. No tetramer-positive T cells were detected in DTH biopsies injected with unloaded DC or KLH-loaded DC. Strikingly, in 6 of 7 patients in whom no tetramer-positive cells were found in freshly isolated PBMC, significant numbers (up to $45 \%$ ) of tetramer-positive T cells were present in their cultured DTH biopsies taken at the same time point. Cytokine production and cytotoxicity of DIL upon co-culture with the appropriate target cells were fully correlated with the specificity in the tetramer analysis. Moreover, DTH reactions induced with DC pulsed with the gp100 peptides accumulated gp100-specific T cells and not tyrosinase and vice versa (Fig. 2). Finally, in situ tetramer staining on cryo-sections revealed that gp100/tyr-specific tetramer-positive cells were specifically present in the infiltrating T-cell clusters. Control tetramers against MART-1, HIV or EBV were negative [16]. Collectively, these data not only indicate that significant numbers of tetramer-positive $\mathrm{T}$ cells accumulate in the DTH site but also demonstrated that these $\mathrm{T}$ cells specifically produced cytokines (Fig. 2) and/or are cytotoxic for tumor antigen expressing target cells (data not shown)[15].

Next, we compared the clinical and immunological data of 26 stage IV melanoma patients (Fig. 3). Inclusion criteria of patients are described previously [19]. Patients had documented progressive disease within 2 months before study entry, serum lactate dehydrogenase $\leq 2 \times$ the upper limit of normal, no prior chemotherapy or immunotherapy within 3 months before study entry, and no residual toxicity from prior treatments. Of these patients, 15 patients had progressive disease (PD), 9 patients had stable disease with $>4$ months duration (SD), and 2 patients, one with multiple liver metastases at time of inclusion, are in complete remission (CR). No tumor-reactive DIL were found in 13 of the 15 patients with PD. Of the 9 patients with SD, 4 patients with specific $\mathrm{T}$ cells had a progression free survival of $>42$, 22, 12, and 4.5 months (median 12 months). In the 5 patients with SD without tumor-reactive DIL the median progression free survival was 6 months (range 11-4.5). Both patients in CR ( $>60$ and $>42$ months) had tumor-specific $\mathrm{T}$ cells. Although the number of patients in this study is limited, a statistically significant $(P=0.0012)$ correlation was observed between the presence of tumor-specific T-cell reactivity and progression free survival [15]. The results were confirmed in 31 stage III melanoma patients.

\section{Optimizing DC capabilities by RNA technology}

Besides the production of highly reproducible GMP quality controlled batches of DC vaccines, in vitro and in vivo tools to analyze B and T-cell responses are developed and injected DC can now be visualized in the patient by advanced imaging technology. Another major breakthrough is the application of RNA transfected DC that express complete tumor antigens. This has now proven to be effective and safe in patients and, in comparison to gene therapy, RNA transfection is much more straight forward.

Cellular therapy with dendritic cells is still in its infancy, but a number of variables are recognized that can contribute to exploit its full potential. In particular, monocyte-derived DC may not seem optimally equipped for their task in vivo. In this context, RNA technology is a promising new tool to achieve temporarily expression or suppression of specific proteins to optimize DC function.

Recent findings have shown that DC transfected with RNA encoding the full-length tumor antigens express the corresponding protein in vivo for a prolonged period of time. Moreover, these RNA transfected DC are able to induce anti-tumor responses in patients. But one can think 
Fig. 2 Specificity in DTH-infiltrated leukocyte (DIL) cultures derived from patients vaccinated with peptide-loaded DC. a In DIL cultured from a DTH performed with DC loaded with gp100 and KLH only T cells positive for the gp100 tetramers were observed. Tyrosinase tetramer-positive cells were observed in the DIL derived from a DTH induced with tyrosinase peptideloaded DC. The production of IFN $\gamma$ corresponded with the observed tetramer positivity. b DIL derived from a DTH site induced by DC loaded with gp100 and KLH did not produce cytokines in response to the HLA-A2.1positive melanoma cell line BLM transfected with control antigen $\mathrm{G} 250$ (a) whereas BLM transfected with gp100 was recognized $(b)$. The DIL culture also recognized an HLA-A2.1positive melanoma cell line expressing both gp100 and tyrosinase $(c)$

\section{A}

DTH performed with:

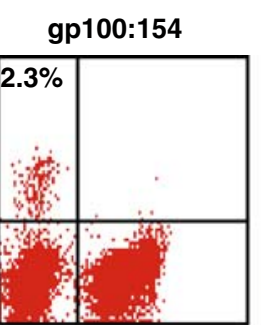

tyrosinase
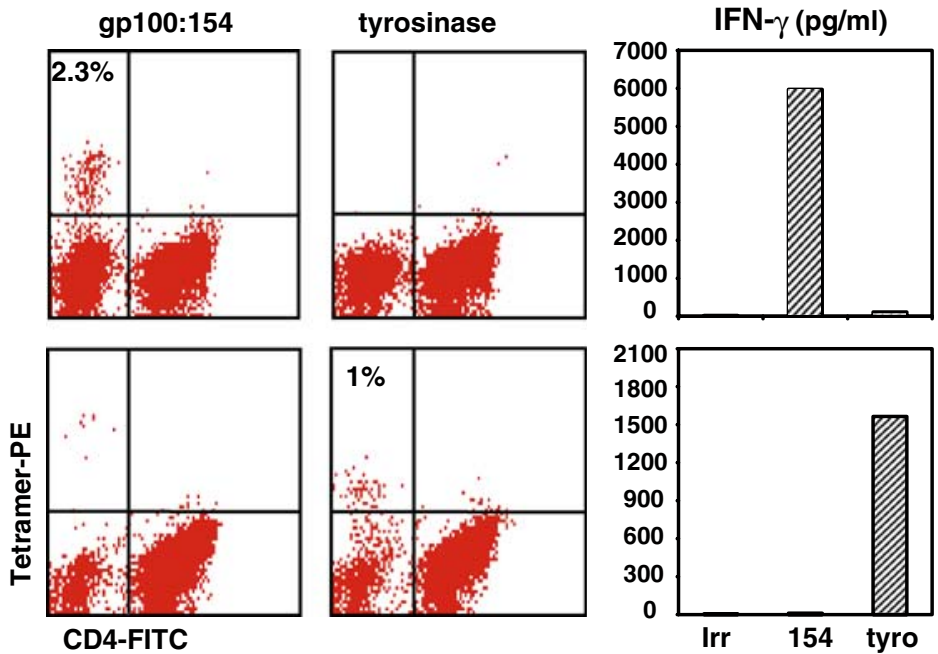

$\underline{\mathrm{DC}}+$ tyro $+\mathrm{KLH}$

B

DTH performed with:

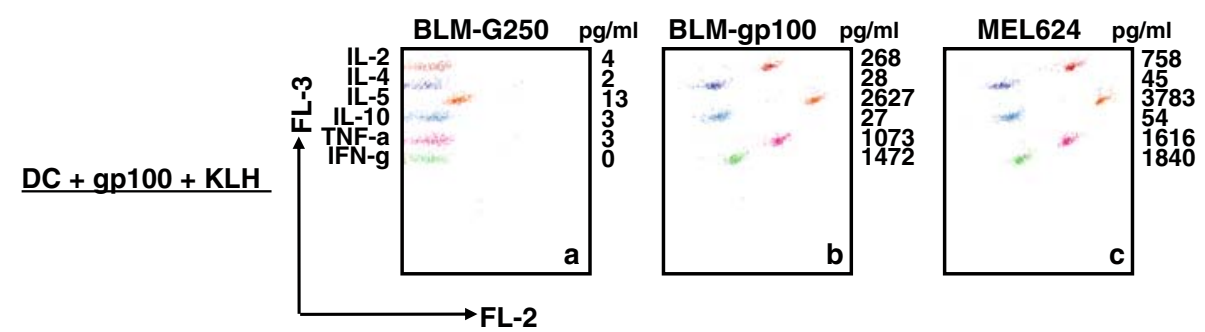

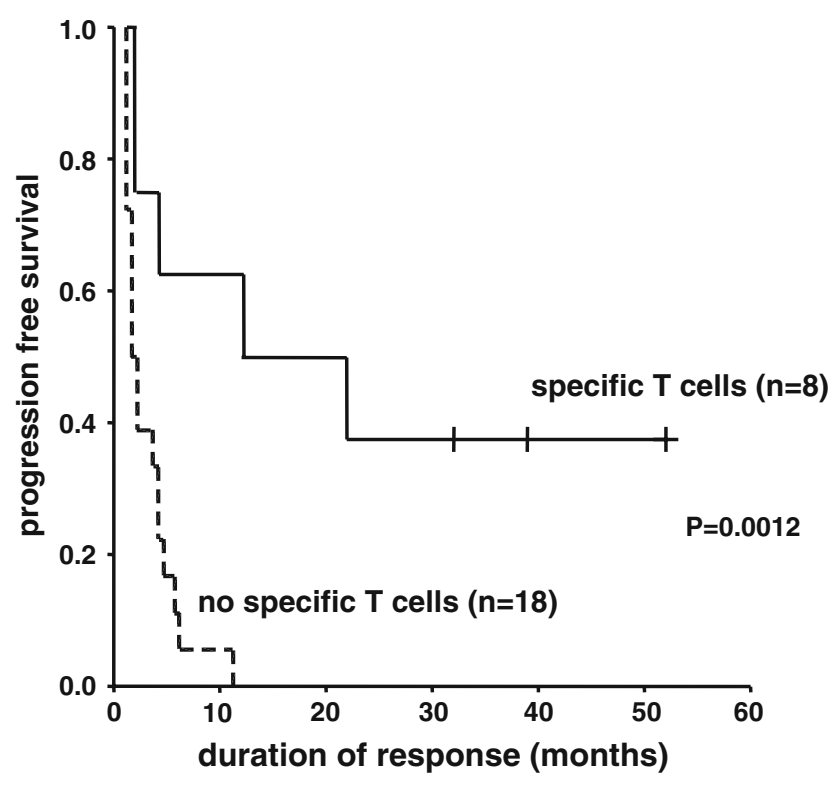

Fig. 3 Presence of tetramer-specific T cells highly correlates with progression free survival in melanoma patients. Correlation between the presence of specific $\mathrm{T}$ cells and clinical outcome is shown in this plot comparing the progression free survival of stage IV melanoma patients with (closed line) and without (hatched line) tumor-specific T cells in their DTH-infiltrated lymphocytes of a broad range of applications of this technology to improve the functional capabilities of monocyte-derived dendritic cells.

During our investigations we observed that the majority of injected DC die early by apoptosis and necrosis. After injection the cells encounter hypoxic conditions and it is known that hypoxia inhibits migration of DC, likely because it blocks the production of metalloproteases [65]. Similarly, Decoy receptor 3 was shown to be upregulated by DC that propagates apoptotic signals [64]. Inhibition of this and other death inducing pathways may significantly increase DC survival.

Secondly, migration of current monocyte-derived DC in vivo is poor, their migration may be impaired due to limited chemokine receptor and cell adhesion receptor functioning. By exploiting RNA technology we might enhance expression of the chemokine CCR7, crucial for lymph node migration. Similarly, induced production of GM-CSF and IL-15 [47] might directly or indirectly enhance DC migration.

Next, RNA technology can be exploited to improve DC maturation and T-cell stimulation. Toll-like receptors have been shown to be of key importance in DC maturation and subsequent induction of immunity through the 
upregulation of cytokines/chemokines and co-stimulatory molecules. To enhance DC maturation DC might be transfected with RNA encoding constitutively active TLRs or RNAs encoding co-stimulatory molecules, like CD70 and CD40L, can be introduced [67]. Expression of CD40L in DC has previously been reported to enhance the magnitude of CD4+ and CD8+ $\mathrm{T}$-cell responses in preclinical models [21, 28]. Recently, CD70 has emerged as a key molecule for priming of CD8+ T-cell responses [7]. RNA interference to optimize $\mathrm{T}$-cell stimulation by ex vivo generated DC by another means is to induce expression of pro-inflammatory cytokines like interleukin-12 and type I interferons.

Aside expression of activatory molecules in DC, it is becoming more and more evident that down regulatory mechanisms are in place that limit the DC's potential as a vaccine adjuvant. Recent murine data have demonstrated that SOCS1 (suppressor of cytokine signaling 1) expression restricts the dendritic cells' ability to break tolerance and induce antitumor immunity [24, 56]. We have recently demonstrated that upon human DC maturation SOCS1 as well as SOCS3 are also rapidly upregulated. Therefore, silencing of inhibitory molecules like SOCS 1 and IL-10 by RNA interference might be another means to improve human DC-based cancer vaccines.

Furthermore, one of the most potent factors limiting vaccine efficacy is the immune suppressive activity of the regulatory $\mathrm{T}$ cell (Treg). Remarkably, several reports indicate the rapid expansion of Treg following immunotherapy, including following DC vaccination. TGF $\beta$ is a cytokine required for the development of regulatory $\mathrm{T}$ cells. Another Treg stimulatory molecule/pathway in DC as a candidate to silence concerns the enzyme indoleamine-2,3-dioxygenase (IDO). IDO1 appears most crucial for tryptophan catabolism and immune suppression $[32,50]$.

\section{In vivo targeting of $\mathrm{DC}$}

Direct targeting of antigens to DC surface receptors in vivo might replace laborious and expensive ex vivo culturing, and facilitate large-scale application of DC-based vaccination therapies. A major advantage of in vivo targeting strategies is that they can be produced in bulk quantities, whereas vaccines based on DC loaded with antigens ex vivo require tailor-made procedures for each individual. In addition, the opportunity to target natural DC-subsets and at multiple sites in vivo might be preferable above loading more artificial ex vivo cultured DC. However, ex vivo culture conditions allow careful control of maturation and activation [62].

Many of the receptors that are studied in targeting strategies belong to the C-type lectin receptor (CLR) family. The
CLRs are a family of calcium-dependent lectins that share primary structural homology in their carbohydrate domain. Through this domain, CLRs bind to specific self or non-self sugar residues and are implicated in antigen capture and endocytosis. In our targeting studies we mainly investigated the targeting of DC-SIGN. DC-SIGN is predominantly expressed on immature DC and at lower levels on mature DC and macrophages [9, 29, 58]. By cloning the hypervariable domains of a mouse antibody specific for human DCSIGN into human framework regions, we obtained a humanized antibody. We demonstrated that this antibody efficiently targets myeloid APC in vivo and reached saturation with one single dose. The binding of the humanized antibody to DC-SIGN showed high affinity and facilitated endocytosis. Furthermore, targeted delivery to human monocyte-derived DC of a model antigen conjugated to the humanized DC-SIGN-specific antibody leads to presentation of the antigen by MHC class I and II molecules and elicits both naive and memory $\mathrm{T}$-cell responses in vitro [61].

The CLR targeting strategies that are most likely to enter the clinic in the near future target DC-SIGN, CD205 (DEC205) and the mannose receptor. Of these, DC-SIGN seems the most DC/macrophage lineage-specific receptor, which might be advantageous since the targeting vector will not be scavenged by other cell types that could result in lower targeting efficiencies and undesirable side-effects. The expression of CD205 for example is in humans less restricted than in mice. Although human CD205 expression levels are highest in mature DC, CD205 is also expressed by B cells, T cells, monocytes, macrophages and NK cells [39]. CD205 however seems to be more potent in mediating cross-presentation in vitro compared to the other two receptors. Furthermore, due to lack of direct control in these targeting strategies, the duration and stability of the vaccine following administration will be difficult to determine.

\section{Conclusions and future prospects}

Dendritic cell immunotherapy has been introduced in the clinic. It has proven to be feasible, non-toxic and effective in some cancer patients, particularly if the DC are appropriately matured and activated. However, many questions still remain. One of the concerns related to ex vivo generated $\mathrm{DC}$ is how to ensure effective migration to the T-cell areas in the lymph node. In this context, we are pursuing the enhancement of migration of ex vivo generated DC by preconditioning the skin with inflammatory cytokines. The recent application of RNA technology in cellular therapy has paved the way to the next generation of dendritic cellbased therapies. Different aspects of DC biology can now be optimized to enhance immunological and clinical 
responses. One can think of exploiting ex vivo generated DC equipped with enhanced expression of chemokine receptors to locate lymph nodes, silenced apoptotic pathways to increase longevity and upregulated production of pro-inflammatory cytokines to skew naive $\mathrm{T}$ cells. These multiple approaches need to be investigated in small twoarmed principle of concept trials with thorough immune monitoring, in order to increase the clinical efficacy of DCbased cancer vaccines. A second promising approach that circumvents many of the posed hurdles with ex vivo loaded $\mathrm{DC}$ is in vivo targeting. Targeting studies using members of the CLR family have paved the way to clinical studies.

Open Access This article is distributed under the terms of the Creative Commons Attribution Noncommercial License which permits any noncommercial use, distribution, and reproduction in any medium, provided the original author(s) and source are credited.

\section{References}

1. Adema GJ, Hartgers F, Verstraten R, de Vries E, Marland G, Menon S, Foster J, Xu Y, Nooyen P, McClanahan T, Bacon KB, Figdor CG (1997) A dendritic-cell-derived C-C chemokine that preferentially attracts naive $\mathrm{T}$ cells. Nature 387:713-717

2. Altman JD, Moss PA, Goulder PJ, Barouch DH, McHeyzer-Williams MG, Bell JI, McMichael AJ, Davis MM (1996) Phenotypic analysis of antigen-specific T lymphocytes. Science 274:94-96

3. Bakker AB, Schreurs MW, de Boer AJ, Kawakami Y, Rosenberg SA, Adema GJ, Figdor CG (1994) Melanocyte lineage-specific antigen gp100 is recognized by melanoma-derived tumor-infiltrating lymphocytes. J Exp Med 179:1005-1009

4. Bakker AB, van der Burg SH, Huijbens RJ, Drijfhout JW, Melief CJ, Adema GJ, Figdor CG (1997) Analogues of CTL epitopes with improved MHC class-I binding capacity elicit anti-melanoma CTL recognizing the wild-type epitope. Int J Cancer 70:302-309

5. Banchereau J, Steinman RM (1998) Dendritic cells and the control of immunity. Nature 392:245-252

6. Banchereau J, Ueno H, Dhodapkar M, Connolly J, Finholt JP, Klechevsky E, Blanck JP, Johnston DA, Palucka AK, Fay J (2005) Immune and clinical outcomes in patients with stage IV melanoma vaccinated with peptide-pulsed dendritic cells derived from CD34+ progenitors and activated with type I interferon. J Immunother 28:505-516

7. Borst J, Hendriks J, Xiao Y (2005) CD27 and CD70 in T cell and B cell activation. Curr Opin Immunol 17:275-281

8. Boullart AC, Aarntzen EH, Verdijk P, Jacobs JF, Schuurhuis DH, Benitez-Ribas D, Schreibelt G, van de Rakt MW, Scharenborg NM, de Boer A, Kramer M, Figdor CG, Punt CJ, Adema GJ, de Vries IJ (2008) Maturation of monocyte-derived dendritic cells with Toll-like receptor 3 and 7/8 ligands combined with prostaglandin $\mathrm{E}(2)$ results in high interleukin-12 production and cell migration. Cancer Immunol Immunother [Epub ahead of print]

9. Bozzacco L, Trumpfheller C, Siegal FP, Mehandru S, Markowitz M, Carrington M, Nussenzweig MC, Piperno AG, Steinman RM (2007) DEC-205 receptor on dendritic cells mediates presentation of HIV gag protein to CD8+ T cells in a spectrum of human MHC I haplotypes. Proc Natl Acad Sci USA 104:1289-1294

10. Brichard V, Van Pel A, Wolfel T, Wolfel C, De Plaen E, Lethe B, Coulie P, Boon T (1993) The tyrosinase gene codes for an antigen recognized by autologous cytolytic $\mathrm{T}$ lymphocytes on HLA-A2 melanomas. J Exp Med 178:489-495
11. Britten CM, Janetzki S, van der Burg SH, Gouttefangeas C, Hoos A (2008) Toward the harmonization of immune monitoring in clinical trials: quo vadis? Cancer Immunol Immunother 57:285-288

12. Bulte JW, Kraitchman DL (2004) Iron oxide MR contrast agents for molecular and cellular imaging. NMR Biomed 17:484-499

13. Celluzzi CM, Mayordomo JI, Storkus WJ, Lotze MT, Falo LD Jr (1996) Peptide-pulsed dendritic cells induce antigen-specific CTL-mediated protective tumor immunity. J Exp Med 183:283287

14. Connerotte T, Van Pel A, Godelaine D, Tartour E, Schuler-Thurner B, Lucas S, Thielemans K, Schuler G, Coulie PG (2008) Functions of Anti-MAGE T-cells induced in melanoma patients under different vaccination modalities. Cancer Res 68:3931-3940

15. de Vries IJ, Bernsen MR, Lesterhuis WJ, Scharenborg NM, Strijk SP, Gerritsen MJ, Ruiter DJ, Figdor CG, Punt CJ, Adema GJ (2005) Immunomonitoring tumor-specific T cells in delayed-type hypersensitivity skin biopsies after dendritic cell vaccination correlates with clinical outcome. J Clin Oncol 23:5779-5787

16. De Vries IJ, Bernsen MR, van Geloof WL, Scharenborg NM, Lesterhuis WJ, Rombout PD, Van Muijen GN, Figdor CG, Punt CJ, Ruiter DJ, Adema GJ (2007) In situ detection of antigen-specific T cells in cryo-sections using MHC class I tetramers after dendritic cell vaccination of melanoma patients. Cancer Immunol Immunother 56:1667-1676

17. de Vries IJ, Eggert AA, Scharenborg NM, Vissers JL, Lesterhuis WJ, Boerman OC, Punt CJ, Adema GJ, Figdor CG (2002) Phenotypical and functional characterization of clinical grade dendritic cells. J Immunother 25:429-438

18. De Vries IJ, Krooshoop DJ, Scharenborg NM, Lesterhuis WJ, Diepstra JH, Van Muijen GN, Strijk SP, Ruers TJ, Boerman OC, Oyen WJ, Adema GJ, Punt CJ, Figdor CG (2003) Effective migration of antigen-pulsed dendritic cells to lymph nodes in melanoma patients is determined by their maturation state. Cancer Res 63:12-17

19. de Vries IJ, Lesterhuis WJ, Scharenborg NM, Engelen LP, Ruiter DJ, Gerritsen MJ, Croockewit S, Britten CM, Torensma R, Adema GJ, Figdor CG, Punt CJ (2003) Maturation of dendritic cells is a prerequisite for inducing immune responses in advanced melanoma patients. Clin Cancer Res 9:5091-5100

20. Dhodapkar MV, Steinman RM, Krasovsky J, Munz C, Bhardwaj $\mathrm{N}$ (2001) Antigen-specific inhibition of effector T cell function in humans after injection of immature dendritic cells. J Exp Med 193:233-238

21. Diehl L, den Boer AT, Schoenberger SP, van der Voort EI, Schumacher TN, Melief CJ, Offringa R, Toes RE (1999) CD40 activation in vivo overcomes peptide-induced peripheral cytotoxic T-lymphocyte tolerance and augments anti-tumor vaccine efficacy. Nat Med 5:774-779

22. Dunbar PR, Ogg GS, Chen J, Rust N, van der Bruggen P, Cerundolo V (1998) Direct isolation, phenotyping and cloning of low-frequency antigen-specific cytotoxic T lymphocytes from peripheral blood. Curr Biol 8:413-416

23. Eggert AA, Schreurs MW, Boerman OC, Oyen WJ, de Boer AJ, Punt CJ, Figdor CG, Adema GJ (1999) Biodistribution and vaccine efficiency of murine dendritic cells are dependent on the route of administration. Cancer Res 59:3340-3345

24. Evel-Kabler K, Song XT, Aldrich M, Huang XF, Chen SY (2006) SOCS1 restricts dendritic cells' ability to break self tolerance and induce antitumor immunity by regulating IL-12 production and signaling. J Clin Invest 116:90-100

25. Fay JW, Palucka AK, Paczesny S, Dhodapkar M, Johnston DA, Burkeholder S, Ueno H, Banchereau J (2006) Long-term outcomes in patients with metastatic melanoma vaccinated with melanoma peptide-pulsed CD34(+) progenitor-derived dendritic cells. Cancer Immunol Immunother 55:1209-1218

26. Fernandez NC, Lozier A, Flament C, Ricciardi-Castagnoli P, Bellet D, Suter M, Perricaudet M, Tursz T, Maraskovsky E, 
Zitvogel L (1999) Dendritic cells directly trigger NK cell functions: cross-talk relevant in innate anti-tumor immune responses in vivo. Nat Med 5:405-411

27. Figdor CG, de Vries IJ, Lesterhuis WJ, Melief CJ (2004) Dendritic cell immunotherapy: mapping the way. Nat Med 10:475-480

28. French RR, Chan HT, Tutt AL, Glennie MJ (1999) CD40 antibody evokes a cytotoxic T-cell response that eradicates lymphoma and bypasses T-cell help. Nat Med 5:548-553

29. Geijtenbeek TB, Torensma R, van Vliet SJ, van Duijnhoven GC, Adema GJ, van Kooyk Y, Figdor CG (2000) Identification of DC-SIGN, a novel dendritic cell-specific ICAM-3 receptor that supports primary immune responses. Cell 100:575-557585

30. Haanen JB, van Oijen MG, Tirion F, Oomen LC, Kruisbeek AM, Vyth-Dreese FA, Schumacher TN (2000) In situ detection of virus- and tumor-specific T-cell immunity. Nat Med 6:1056-1060

31. Herr W, Wolfel T, Heike M, Meyer zum Buschenfelde KH, Knuth A (1994) Frequency analysis of tumor-reactive cytotoxic T lymphocytes in peripheral blood of a melanoma patient vaccinated with autologous tumor cells. Cancer Immunol Immunother 39:9399

32. Hill M, Tanguy-Royer S, Royer P, Chauveau C, Asghar K, Tesson L, Lavainne F, Remy S, Brion R, Hubert FX, Heslan M, Rimbert M, Berthelot L, Moffett JR, Josien R, Gregoire M, Anegon I (2007) IDO expands human CD4 + CD25 high regulatory T cells by promoting maturation of LPS-treated dendritic cells. Eur J Immunol 37:3054-3062

33. Hoos A, Parmiani G, Hege K, Sznol M, Loibner H, Eggermont A, Urba W, Blumenstein B, Sacks N, Keilholz U, Nichol G (2007) A clinical development paradigm for cancer vaccines and related biologics. J Immunother 30:1-15

34. Jiang W, Swiggard WJ, Heufler C, Peng M, Mirza A, Steinman RM, Nussenzweig MC (1995) The receptor DEC-205 expressed by dendritic cells and thymic epithelial cells is involved in antigen processing. Nature 375:151-155

35. Jonuleit H, Schmitt E, Schuler G, Knop J, Enk AH (2000) Induction of interleukin 10-producing, nonproliferating CD4(+) T cells with regulatory properties by repetitive stimulation with allogeneic immature human dendritic cells. J Exp Med 192:1213-1222

36. Kadowaki N, Antonenko S, Lau JY, Liu YJ (2000) Natural interferon alpha/beta-producing cells link innate and adaptive immunity. J Exp Med 192:219-226

37. Kalinski P, Giermasz A, Nakamura Y, Basse P, Storkus WJ, Kirkwood JM, Mailliard RB (2005) Helper role of NK cells during the induction of anticancer responses by dendritic cells. Mol Immunol 42:535-539

38. Kalinski P, Hilkens CM, Wierenga EA, Kapsenberg ML (1999) T-cell priming by type- 1 and type- 2 polarized dendritic cells: the concept of a third signal. Immunol Today 20:561-567

39. Kato M, McDonald KJ, Khan S, Ross IL, Vuckovic S, Chen K, Munster D, MacDonald KP, Hart DN (2006) Expression of human DEC-205 (CD205) multilectin receptor on leukocytes. Int Immunol $18: 857-869$

40. Liu YJ (2001) Dendritic cell subsets and lineages, and their functions in innate and adaptive immunity. Cell 106:259-262

41. Lonchay C, van der Bruggen P, Connerotte T, Hanagiri T, Coulie P, Colau D, Lucas S, Van Pel A, Thielemans K, van Baren N, Boon T (2004) Correlation between tumor regression and $\mathrm{T}$ cell responses in melanoma patients vaccinated with a MAGE antigen. Proc Natl Acad Sci USA 101(Suppl. 2):14631-8

42. Mackensen A, Krause T, Blum U, Uhrmeister P, Mertelsmann R, Lindemann A (1999) Homing of intravenously and intralymphatically injected human dendritic cells generated in vitro from CD34+ hematopoietic progenitor cells. Cancer Immunol Immunother 48:118-122

43. Matzinger P (1994) Tolerance, danger, and the extended family. Annu Rev Immunol 12:991-1045
44. Mayordomo JI, Zorina T, Storkus WJ, Zitvogel L, Celluzzi C, Falo LD, Melief CJ, Ildstad ST, Kast WM, Deleo AB et al (1995) Bone marrow-derived dendritic cells pulsed with synthetic tumour peptides elicit protective and therapeutic antitumour immunity. Nat Med 1:1297-1302

45. Miller JS, Soignier Y, Panoskaltsis-Mortari A, McNearney SA, Yun GH, Fautsch SK, McKenna D, Le C, Defor TE, Burns LJ, Orchard PJ, Blazar BR, Wagner JE, Slungaard A, Weisdorf DJ, Okazaki IJ, McGlave PB (2005) Successful adoptive transfer and in vivo expansion of human haploidentical NK cells in patients with cancer. Blood 105:3051-3057

46. Nestle FO, Banchereau J, Hart D (2001) Dendritic cells: on the move from bench to bedside. Nat Med 7:761-765

47. Ohteki T, Tada H, Ishida K, Sato T, Maki C, Yamada T, Hamuro J, Koyasu S (2006) Essential roles of DC-derived IL-15 as a mediator of inflammatory responses in vivo. J Exp Med 203:2329-2338

48. Palucka AK, Ueno H, Fay JW, Banchereau J (2007) Taming cancer by inducing immunity via dendritic cells. Immunol Rev 220:129-150

49. Parmiani G, Castelli C, Santinami M, Rivoltini L (2007) Melanoma immunology: past, present and future. Curr Opin Oncol 19:121-127

50. Puccetti P, Grohmann U (2007) IDO and regulatory T cells: a role for reverse signalling and non-canonical NF-kappaB activation. Nat Rev Immunol 7:817-823

51. Rescigno M, Borrow $\mathrm{P}$ (2001) The host-pathogen interaction: new themes from dendritic cell biology. Cell 106:267-270

52. Ruggeri L, Capanni M, Urbani E, Perruccio K, Shlomchik WD, Tosti A, Posati S, Rogaia D, Frassoni F, Aversa F, Martelli MF, Velardi A (2002) Effectiveness of donor natural killer cell alloreactivity in mismatched hematopoietic transplants. Science 295:2097-2100

53. Sallusto F, Lanzavecchia A (1994) Efficient presentation of soluble antigen by cultured human dendritic cells is maintained by granulocyte/macrophage colony-stimulating factor plus interleukin 4 and downregulated by tumor necrosis factor alpha. J Exp Med 179:1109-1118

54. Sallusto F, Lanzavecchia A (1999) Mobilizing dendritic cells for tolerance, priming, and chronic inflammation. J Exp Med 189:611-614

55. Scheibenbogen C, Lee KH, Stevanovic S, Witzens M, Willhauck M, Waldmann V, Naeher H, Rammensee HG, Keilholz U (1997) Analysis of the $\mathrm{T}$ cell response to tumor and viral peptide antigens by an IFNgamma-ELISPOT assay. Int J Cancer 71:932-936

56. Shen L, Evel-Kabler K, Strube R, Chen SY (2004) Silencing of SOCS1 enhances antigen presentation by dendritic cells and antigen-specific anti-tumor immunity. Nat Biotechnol 22:1546-1553

57. Shevach EM, McHugh RS, Piccirillo CA, Thornton AM (2001) Control of T-cell activation by CD4+ CD25+ suppressor T cells. Immunol Rev 182:58-67

58. Soilleux EJ, Morris LS, Leslie G, Chehimi J, Luo Q, Levroney E, Trowsdale J, Montaner LJ, Doms RW, Weissman D, Coleman N, Lee B (2002) Constitutive and induced expression of DC-SIGN on dendritic cell and macrophage subpopulations in situ and in vitro. J Leukoc Biol 71:445-457

59. Steinman RM (2007) Dendritic cells: understanding immunogenicity. Eur J Immunol 37(Suppl 1):S53-S60

60. Steinman RM, Banchereau J (2007) Taking dendritic cells into medicine. Nature 449:419-426

61. Tacken PJ, de Vries IJ, Gijzen K, Joosten B, Wu D, Rother RP, Faas SJ, Punt CJ, Torensma R, Adema GJ, Figdor CG (2005) Effective induction of naive and recall T-cell responses by targeting antigen to human dendritic cells via a humanized anti-DCSIGN antibody. Blood 106:1278-1285

62. Tacken PJ, de Vries IJ, Torensma R, Figdor CG (2007) Dendriticcell immunotherapy: from ex vivo loading to in vivo targeting. Nat Rev Immunol 7:790-802 
63. Verdijk P, Scheenen TW, Lesterhuis WJ, Gambarota G, Veltien AA, Walczak P, Scharenborg NM, Bulte JW, Punt CJ, Heerschap A, Figdor CG, de Vries IJ (2007) Sensitivity of magnetic resonance imaging of dendritic cells for in vivo tracking of cellular cancer vaccines. Int J Cancer 120:978-984

64. You RI, Chang YC, Chen PM, Wang WS, Hsu TL, Yang CY, Lee CT, Hsieh SL (2008) Apoptosis of dendritic cells induced by decoy receptor 3 (DcR3). Blood 111:1480-1488

65. Zhao W, Darmanin S, Fu Q, Chen J, Cui H, Wang J, Okada F, Hamada J, Hattori Y, Kondo T, Hamuro J, Asaka M, Kobayashi M (2005) Hypoxia suppresses the production of matrix metallopro- teinases and the migration of human monocyte-derived dendritic cells. Eur J Immunol 35:3468-3477

66. Zitvogel L, Mayordomo JI, Tjandrawan T, DeLeo AB, Clarke MR, Lotze MT, Storkus WJ (1996) Therapy of murine tumors with tumor peptide-pulsed dendritic cells: dependence on T cells, B7 costimulation, and T helper cell 1-associated cytokines. J Exp Med 183:87-97

67. Bonehill A, Tuyaerts S, Van Nuffel AM, Heirman C, Bos TJ, Fostier K, Neyns B, Thielemans K (2008) Enhancing the T-cell stimulatory capacity of human dendritic cells by co-electroporation with CD40L, CD70 and constitutively active TLR4 encoding mRNA. Mol Ther 16:1170-1180 